\title{
Purification of Lytic Enzymes for Radioresistant Bacteria Produced by Achromobacter lunatus
}

\author{
Hiroshi Watanabe and Tomotaro SATo* \\ Takasaki Radiation Chemistry Research Establishment, \\ Japan Atomic Energy Research Institute, \\ Takasaki, Gunma 370-12, Japan \\ Received November 12, 1980
}

\begin{abstract}
The crude enzyme fraction of precipitates resulting from the addition of $70 \%$ alcohol to the culture filtrate of $A$. lunatus was separated by CM-Sephadex and Sephadex G-75 chromatography into 13 fractions having lytic activity for $M$. radiodurans, $M$. lysodeikticus and $P$. radiora. Five of the fractions showed similar lytic activity spectra, but the other fractions were separated by the specificities of their lytic activities. This result indicates that the wide lytic spectrum of the crude enzyme against microorganisms is attributable to the action of many lytic enzymes. All fractions, except for P2-2 fraction (designated as the P2-2. enzyme), contained at least two proteins as determined by disc gel electrophoresis. The P2-2 enzyme was purified 34-fold by rechromatography on Sephadex G-75, and appeared to be homogeneous on disc gel electrophoresis. The enzyme was able to lyse intact cells of $M$. radiodurans and $M$. lysodeikticus without detergent, and those of $P$. radiora with detergent, but was not able to digest casein.
\end{abstract}

Most radioresistant bacteria are not lysed easily by egg white lysozyme (EC 3.2.1.17), which is widely used to disintegrate bacterial cell walls. Therefore, it was difficult to study and compare the mechanisms of radioresistance of these bacteria. From some of the experiments carried out for this purpose, the "R1 fraction" of Streptomyces albus $\mathrm{G}^{1)}$ and a peptidase of Achromobacter lyticus ${ }^{2)}$ were found to lyse the cells of Micrococcus radiodurans in the presence of detergents. In addition, the cell walls of $M$. radiodurans were rendered sensitive to decomposition by lysozyme after an extraction with $n$-butanolsaturated buffer. ${ }^{3)}$ However, all these treatments require the presence of alcohol and detergent for lysis by the enzyme. Recently, Yoshinaka et $a l_{.}{ }^{4)}$ and our group ${ }^{5)}$ reported that the lytic enzymes of Cytophaga sp. and of Achromobacter lunatus isolated by Tsumura et $a l^{6 \sim 9)}$ were available for lysis of radioresistant bacteria without alcohol and detergent.

* Present address: Food Research Institute, Tokai Bussan Co., Fukuroi, Shizuoka 437, Japan.
In the previous paper ${ }^{5)}$ it was shown that the crude enzyme from $A$. lunatus was able to lyse various strains of bacteria, including radioresistant bacteria. This paper aims to elucidate whether or not the wide lytic spectrum of crude enzyme is attributable to one enzyme and to purify the lytic enzyme.

\section{MATERIALS AND METHODS}

Enzyme. Crude enzyme was kindly supplied by Amano Pharmaceutical Co., Ltd. (Nagoya, Japan). The enzyme preparation is a lyophilized powder of the precipitate which is produced by adding enough alcohol to make a final concentration of $70 \%$ to the culture filtrate of $A$. lunatus. A. lunatus was grown aerobically at $28^{\circ} \mathrm{C}$ in a culture medium (pH 6.5 ) containing $1 \%$ glucose, $0.5 \%$ ammonium phosphate, $0.1 \%$ yeast extract and $0.05 \%$ magnesium sulfate.

Microorganisms. Pseudomonas radiora $\mathrm{O}-1, \quad M$. radiodurans $\mathrm{R}_{1}$ and $M$. lysodeikticus IAM 1056 were used for the assays of the lytic activities of enzymes. All bacteria were cultured with shaking at $30^{\circ} \mathrm{C}$ for two days in medium containing $1 \%$ polypeptone, $1 \%$ meat extract, $0.5 \%$ glucose, $0.3 \%$ yeast extract and $0.2 \% \mathrm{NaCl}(\mathrm{pH} 7.0)$. When the cells reached the stationary phase of growth, they were harvested by centrifugation, washed, resuspend- 
ed in distilled water and stored in a freezer at $-20^{\circ} \mathrm{C}$.

\section{Lytic activities.}

(i) Bacteriolytic activity. The cells of $M$. radiodurans and $M$. lysodeikticus were suspended in the reaction mixture to give an initial absorbance of 0.9 at $660 \mathrm{~nm}$ with an Hitachi 239 spectrophotometer. The reaction mixture contained $0.03 \mathrm{M}$ Tris- $\mathrm{HCl}$ buffer $(\mathrm{pH} 8.4)$ and $0.2 \mathrm{ml}$ of enzyme solution in a total volume of $5 \mathrm{ml}$. Water replaced the enzyme solution in the control. In the case of $P$. radiora, Triton $\mathrm{X}-100$ was added to the reaction mixture at final concentration of $0.5 \mathrm{~mm}$. The mixture was incubated at $50^{\circ} \mathrm{C}$ for $10 \mathrm{~min}$ with $M$. radiodurans and $M$. lysodeikticus, and with $P$. radiora at $50^{\circ} \mathrm{C}$ for one hour. Reduction of turbidity of the reaction mixture was measured by optical density at $660 \mathrm{~nm}$. One unit of lytic activity was defined as the amount of enzyme causing a change of 0.001 optical density units per min.

(ii) Proteolytic activity. The activity was determined from the digestion of casein by the method of Tsumura et al. ${ }^{73}$

Analytical methods. The amount of protein present was estimated by absorption at $280 \mathrm{~nm}$ assuming $E_{1 \% \mathrm{~cm}}^{1 \%}=10$. Disc gel electrophoresis of the enzymes was carried out with a $\mathrm{pH} 6.6$ polyacrylamide gel using the method of Reisfeld. ${ }^{10}$

\section{RESULTS AND DISCUSSION}

Exactly $2.0 \mathrm{~g}$ of the crude enzyme was dissolved in $20 \mathrm{ml}$ of $0.01 \mathrm{M}$ citrate buffer $(\mathrm{pH}$ 6.4). The solution was sonicated at $0^{\circ} \mathrm{C}$ for $5 \mathrm{~min}$ to decrease the viscosity, and applied to a column $(5 \times 52 \mathrm{~cm})$ of CM-Sephadex which had been equilibrated with the same buffer.
The purification was performed at $5^{\circ} \mathrm{C}$ unless otherwise stated. The lytic activities were eluted with approximately two liters of the citrate buffer. The elution pattern is shown in Fig. 1. The absorbances of F1 and F3 at 280 $\mathrm{nm}$, as seen in the figure, corresponded well to the absorbances at $400 \mathrm{~nm}$. Absorbance at 400 $\mathrm{nm}$ was not detected in fractions after No. 45. The F1 and F3 peaks contain the brown compounds which are seemed in the culture filtrate, and the $F 1$ and $F 2$ peaks have the lytic activities for $M$. radiodurans and $P$. radiora. These activities were lower than those found in other fractions, as is shown later, so these peaks were not fractionated further.

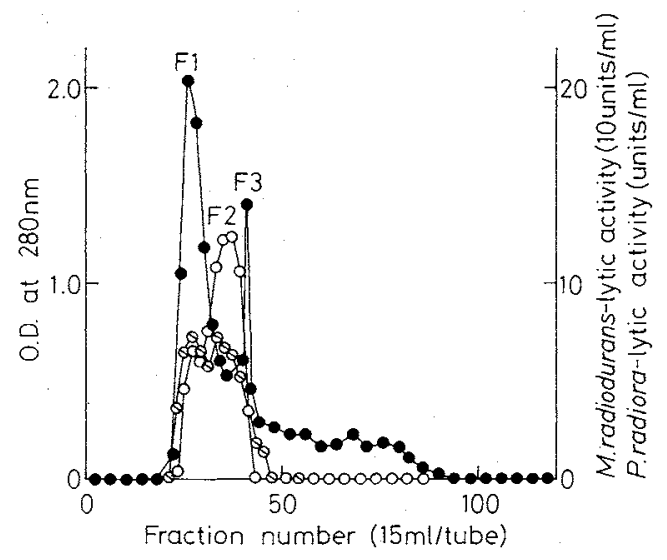

FIG. 1. Elution Pattern of Lytic Activities from CMSephadex C-25 with $0.01 \mathrm{M}$ Citrate Buffer (pH 6.4).

- optical density at $280 \mathrm{~nm} ; O ; M$. radiodurans-lytic activity; $Q ; P$. radiora-lytic activity.

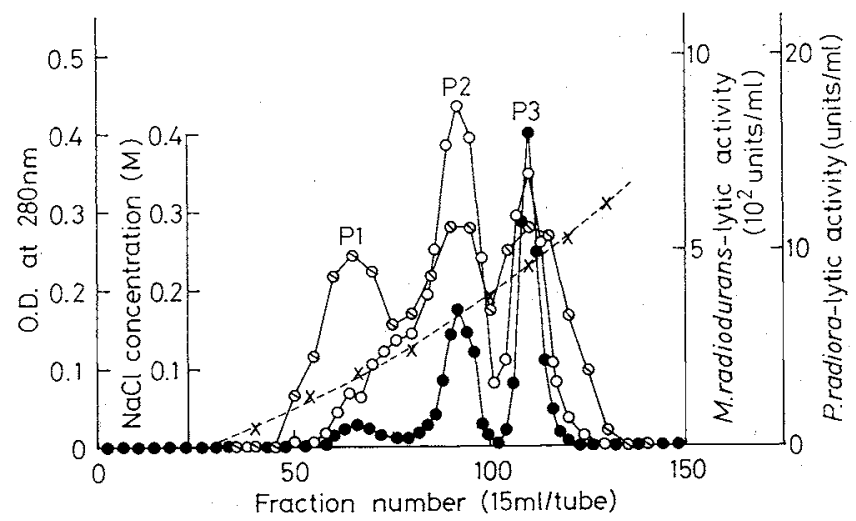

FIG. 2. Chromatogram of Bacteriolytic Enzymes on a Column of CM-Sephadex C-25.

The elution was carried out using a $0 \sim 0.5 \mathrm{M}$ gradient of $\mathrm{NaCl}$ in $0.01 \mathrm{M}$ citrate buffer ( $\mathrm{pH} 6.4$ ).

$x ; \mathrm{NaCl}$ concentration. The other symbols in this figure are the same as those in Fig. 1 . 


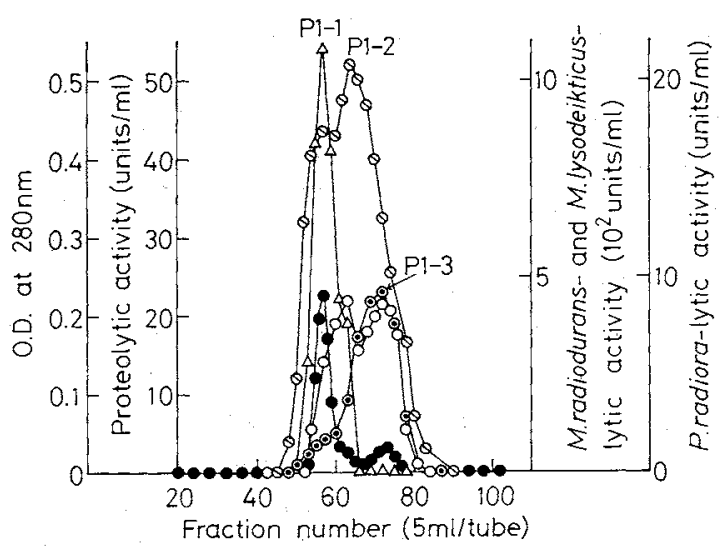

Fig. 3. Gel Filtration of P1 Fraction on Sephadex G-75.

$\odot, M$. lysodeikticus-lytic activity; $\triangle$, proteolytic activity. The other symbols are the same as those in Fig. 1.

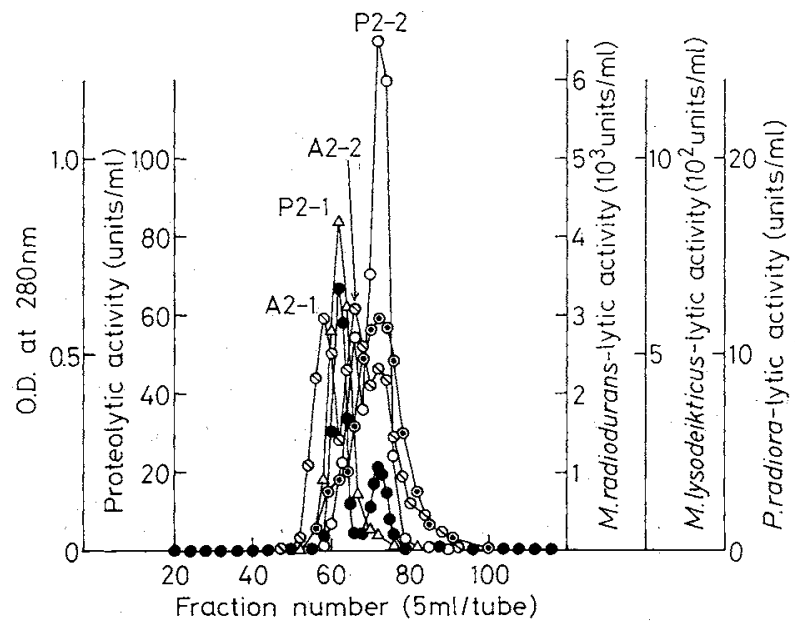

FIG. 4. Gel Filtration of P2 Fraction on Sephadex G-75.

All symbols are the same as those in Fig. 3.

Another sample of crude enzyme as prepared above was absorbed on CM-Sephadex and eluted by a $0 \sim 0.5 \mathrm{M}$ gradient of $\mathrm{NaCl}$ in $0.01 \mathrm{M}$ citrate buffer ( $\mathrm{pH}$ 6.4). A typical chromatographic pattern is shown in Fig. 2. The enzymes were recovered in the $0.07 \sim 0.25 \mathrm{M}$ $\mathrm{NaCl}$ region, and were separated into protein fractions P1, P2 and P3. All of these fractions include lytic activities for $M$. radiodurans and $P$. radiora. The $\mathrm{P} 1$ fraction has a higher activity for $P$. radiora than for $M$. radiodurans. On the contrary, the $\mathrm{P} 2$ and $\mathrm{P} 3$ fractions have higher activities for $M$. radiodurans than for $P$. radiora. Further purification of each fraction was accomplished by the following procedure. The $\mathrm{P} 1$ fraction, consisting of 20 tubes from fraction number 57 to 76 , was concentrated to approximately $5 \mathrm{ml}$ by membrane filtration under pressure using a UM-2 filter in an AMICON model 202 filtration apparatus, and applied to a Sephadex G-75 column $(2.5 \times 85 \mathrm{~cm})$ equilibrated with $0.01 \mathrm{M}$ citrate buffer ( $\mathrm{pH}$ 6.4). Figure 3 shows the gel filtration profiles of the $\mathrm{P} 1$ fraction, which was separated into three additional protein fractions designated P1-1, P1-2 (seen as a small shoulder) and P1-3. The P1-1 and P1-2 fractions easily lysed the cells of $P$. radiora. The 
P1-1 protein also includes a proteolytic activity and a low lytic activity for $M$. lysodeikticus. The Pl-3 protein has no proteolytic activity. This fraction includes the lytic activities for $M$. radiodurans and $M$. lysodeikticus, and may also have an activity for $P$. radiora. The $\mathrm{P} 2$ (tubes $85 \sim 98$ ) and $\mathrm{P} 3$ (tubes $105 \sim 116)$ fractions were concentrated by membrane filtration, and fractionated by Sephadex G-75 according to the same pro-

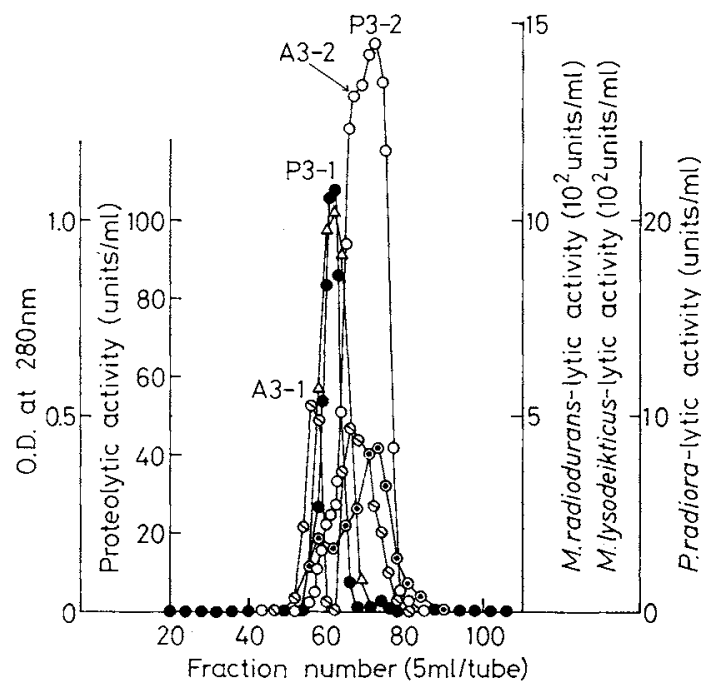

FIG. 5. Gel Filtration of P3 Fraction on Sephadex G75 .

All symbols are the same as those in Fig. 3. cedure used for the P1 fraction. The gel filtration patterns of the $\mathrm{P} 2$ and $\mathrm{P} 3$ proteins are shown in Figs. 4 and 5, respectively. The P2 peak was separated into two protein fractions, P2-1 and P2-2, and two active fractions, A2-1 and $A 2-2$, which did not correspond to protein peaks. The $\mathrm{P} 2-1$ protein has a proteolytic activity and a low lytic activity for $M$. lysodeikticus, while the $\mathrm{P} 2-2$ protein contains all bacteriolytic activities, but is free from proteolytic activity. As shown in Fig. 5, the P3 peak was separated into a main protein fraction, P3-1, and a smaller fraction, P3-2. Two active fractions, A3-1 and A3-2, were also detected. The properties of the eleven fractions as described above are summarized in Table $\mathrm{I}$. Fractions A2-2 and A3-2 show similar lytic activity, and fractions P1-3 and P3-2 show almost the same lytic activity as P2-2. However, the other fractions differ from each other in proteolytic and bacteriolytic activities. The highest lytic activity for $P$. radiora was detected in P1-2, and the highest proteolytic activity was detected in P3-1. In addition, only the P2-2 fraction contained high lytic activities for $M$. radiodurans and $M$. lysodeikticus.

The culture filtrate of $A$. lunatus is capable of lysing the cells of bacteria, yeast and fungi. ${ }^{9}$ The crude enzyme from the culture filtrate is also able to lyse various strains of bacteria,

Table I. Lytic Activities of Eaçh Fraction Separated by Sephadex G-75

\begin{tabular}{|c|c|c|c|c|c|}
\hline \multirow{2}{*}{\multicolumn{2}{|c|}{ Fraction }} & \multicolumn{3}{|c|}{ Bacteriolytic activity } & \multirow{2}{*}{$\begin{array}{c}\text { Proteolytic } \\
\text { activity }\end{array}$} \\
\hline & & $P$. radiora & $M$. radiodurans & M. lysodeikticus & \\
\hline \multirow[t]{3}{*}{ Pl } & P1-1 & + & - & + & + \\
\hline & P1-2 & ++ & + & - & + \\
\hline & $\mathrm{P} 1-3$ & \pm & + & + & - \\
\hline \multirow[t]{4}{*}{$\mathrm{P} 2$} & A2-1 & + & - & - & - \\
\hline & P2-1 & - & - & + & + \\
\hline & A $2-2$ & + & + & - & - \\
\hline & $\mathrm{P} 2-2$ & + & ++ & ++ & - \\
\hline \multirow[t]{4}{*}{ P3 } & A3-1 & + & - & + & - \\
\hline & P3-1 & - & + & - & $+t$ \\
\hline & A3-2 & + & + & - & - \\
\hline & P3-2 & \pm & + & + & - \\
\hline
\end{tabular}

++ , most active; + , active; - , negative; \pm , not distinguished. 

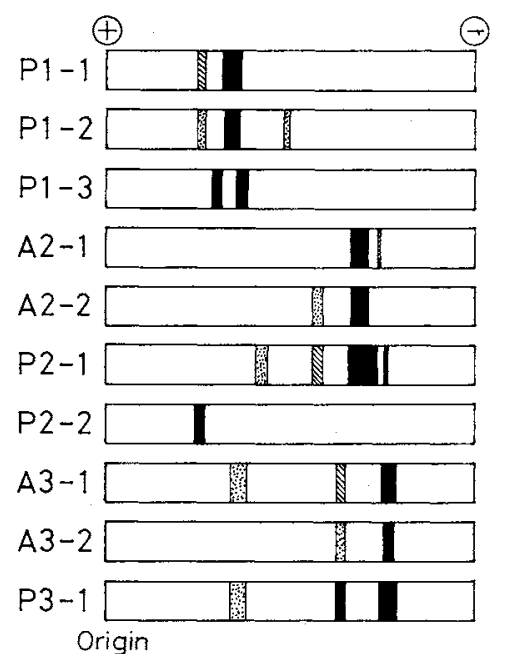

FIG. 6. Disc Gel Electrophoretic Patterns of Each Fraction Separated by Sephadex G-75.

The electrophoresis was carried out using a $\mathrm{pH} 6.6$ polyacrylamide gel with a current of $2 \mathrm{~mA} /$ tube for one hour.

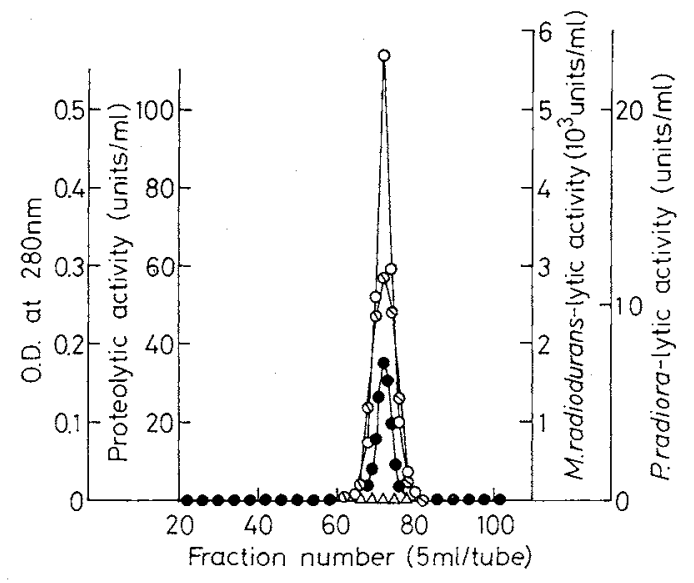

FIG. 7. Rechromatography of the P2-2 Fraction on a Sephadex G-75 Column.

The symbols are the same as those in Fig. 3.

Table II. Purification of the P2-2 Enzyme from a Crude Enzyme Preparation of A. lunatus

\begin{tabular}{lcccc} 
Fraction & $\begin{array}{c}\text { Total } \\
\text { protein } \\
(\mathrm{mg})\end{array}$ & $\begin{array}{c}\text { Total } \\
\text { activity } \\
\left.\text { (units } \times 10^{4}\right)\end{array}$ & $\begin{array}{c}\text { Specific } \\
\text { activity } \\
\text { (units/mg) }\end{array}$ & $\begin{array}{c}\text { Recovery } \\
(\%)\end{array}$ \\
\hline 70\% Alcohol precipitate & 394.5 & 36.1 & 915 & 100 \\
CM-Sephadex I & 21.4 & 12.9 & 6028 & 36 \\
CM-Sephadex II & 16.0 & 10.5 & 6563 & 29 \\
Sephadex G-75 I & 2.7 & 8.5 & 31481 & 24 \\
Sephadex G-75 II & 2.0 & 6.3 & 31500 & 17 \\
\hline
\end{tabular}

a One unit of lytic activity is defined as a change in absorbance of 0.001 at $660 \mathrm{~nm}$ of a suspension of $M$. radiodurans cells in one minute at $50^{\circ} \mathrm{C}$.

including radioresistant bacteria such as $M$. radiodurans, $M$. radioproteolyticus, $M$. sp. $\mathrm{H} 55$ and Arthrobacter radiotolerans $\mathrm{P}-1{ }^{5}{ }^{5}$ In addition, Tsumura et $a l^{7)}$ has determined the activities of protease and glucanase in the culture filtrate. These observations and our results indicate that the wide lytic spectrum is attributable to the action of many lytic enzymes.

Disc gel electrophoretic patterns of each of the fractions at $\mathrm{pH} 6.6$ are shown in Fig. 6. Only the P2-2 fraction showed a single band of protein, while the other fractions consisted of at least two protein bands. Figure 7 shows the rechromatography of P2-2 on Sephadex G-75.
At this step, the P2-2 eluted as a single symmetrical peak, and the lytic activities for $M$. radiodurans and $P$. radiora corresponded to the protein peak. The over-all sequence of the purification procedures is summarized in Table II. Since the crude enzyme included many lytic enzymes, only the degree of purification of P2-2 was estimated. The specific activity of the P2-2 protein was purified 34-fold from that of the crude enzyme, as estimated by $M$. radiodurans-lytic activity. The $\mathrm{P} 2-2$ fraction (designated as the P2-2 enzyme) has no proteolytic activity. Therefore, we examined the digestion of peptidoglycan from the cell walls of $M$. lysodeikticus by the P2-2 enzyme, 
but observed no liberation of reducing groups during digestion. This indicates that the P2-2 enzyme is not a glycosidase. The detailed properties and lytic action of the P2-2 enzyme will be described in the following paper.

Acknowledgments. The authors wish to thank Dr. N. Tsumura, of the National Food Research Institute, for his helpful advice and guidance and a critical reading of the manuscript, and Amano Pharmaceutical Co., Ltd., for the gift of crude enzyme. They also thank Professor H. Iizuka, of Science University of Tokyo, and Dr. M. Takehisa, Dr. $\mathrm{H}$. Ito and Mr. T. Kume for their helpful discussions and encouragement.

\section{REFERENCES}

1) J. C. Dean, P. Feldschreiber and J. T. Lett, Nature,
209, 49 (1966).

2) K. Nakamura, Y. Okazawa, M. Soejima and T. Masaki, Agric. Biol. Chem., 37, 2667 (1973).

3) A. A. Driedger and M. J. Grayston, Can. J. Microbiol., 16, 889 (1970).

4) T. Yoshinaka, K. Yano and H. Yamaguchi, Agric. Biol. Chem., 40, 227 (1976).

5) H. Watanabe, T. Kume, Y. Okazawa and T. Sato, Agric. Biol. Chem., 40, 427 (1976).

6) N. Tsumura and M. Ishikawa, Rep. Food Res. Inst., 26, 17 (1971).

7) N. Tsumura and M. Ishikawa, Rep. Food Res. Inst., 28, 38 (1973).

8) S. Yanai, M. Ishikawa and N. Tsumura, J. Ferment. Technol., 51, 209 (1973).

9) N. Tsumura, M. Ishikawa and S. Yanai, Rep. Food Res. Inst., 29, 42 (1974).

10) R. A. Reisfeld, U. J. Lewis and D. E. Williams, Nature, 195, 281 (1962). 